\title{
Dlaczego dziecko z niepełnosprawnością zwykle staje się uczniem upośledzonym?
}

\author{
KEY WORDS \\ disabled learner, \\ impaired identity, \\ integrated education
}

\begin{abstract}
Gajdzica Zenon, Dlaczego dziecko z niepełnosprawnościq zwykle staje się uczniem upośledzonym? [Why Does a Child with Impairment Usually Become a Disabled Learner?]. Kultura - Społeczeństwo - Edukacja nr 2, 2012, Poznań 2012, pp. 31-40, Adam Mickiewicz University Press. ISBN 978-83-232-2528-7. ISSN 2300-0422

The presented study aims at the identification of these mechanisms in the area of integrated education as well as at showing possible consequences for educational practice and the development of disabled learners. The first is related to the biological model of disability, which is determined by the notion of physiological norm and for which organism impairment is a constitutive feature. What ranks as priority in the second standpoint are special educational needs treated as a derivative of functional disorders. This point of view is particularly visible in some psychological definitions presenting disability as individual functional disorders. The last perspective of viewing the disabled learner which is discussed here is situated in the assumptions of constructivism. Each of the presented standpoints allows for slightly different handling of the disabled learner's school problems. In the presented article, the discussed issues are rooted in the last - constructivist approach.
\end{abstract}

Bycie dzieckiem z niepełnosprawnością wcale nie musi oznaczać bycia uczniem upośledzonym. Trudno jednak zaprzeczyć, że ograniczenie sprawności utrudnia spełnianie wielu ról typowych dla dziecka w wieku szkolnym, w tym także tej jednej z ważniejszych - roli ucznia. Ponadto istnieje wiele mechanizmów sprzyjających nie tylko wrastaniu dziecka niepełnosprawnego w rolę upośledzonego, ale również nabywania tożsamości adekwatnej do tej roli. Celem opracowania jest ich zidentyfikowanie w obszarze kształcenia integracyjnego, ukazanie możliwych konsekwencji dla praktyki edukacyjnej oraz rozwoju samych uczniów niepełnosprawnych. 
Wybór integracyjnej formy kształcenia dla rozpatrzenia wskazanego zagadnienia nie jest przypadkowy. Powszechny w naszym kraju model edukacji integracyjnej charakteryzuje wiele wewnętrznych sprzeczności. Przestrzeń klasy/grupy integracyjnej stanowi miejsce ścierania się wielu rozłącznych założeń, a sama integracja jest procesem balansowania między szansą i zagrożeniem dla uczniów $\mathrm{z}$ niepełnosprawnością. Zobrazowanie tych tez zostanie zaprezentowane w pierwszej części opracowania. Druga obejmuje problematykę ucznia niepełnosprawnego. W trzeciej części zostaną rozpatrzone zagadnienia mechanizmów wrastania w rolę ucznia upośledzonego oraz nabywania tożsamości typowej dla tej roli. Całość zamykają konkluzje końcowe.

\section{Zapętlenia edukacji integracyjnej}

Główną ideą integracji edukacyjnej jest scalanie procesów uczenia się dzieci i młodzieży niepełnosprawnej $\mathrm{w}$ jednym nurcie $\mathrm{z}$ ich pełnosprawnymi rówieśnikami. Naturalnie, w procesie tym nie chodzi wyłącznie o integrację przestrzenną (kształcenie we wspólnej sali), chociaż trudno zaprzeczyć, że jest ona punktem wyjścia, ponieważ integracja musi opierać się na systematycznych, najlepiej bezpośrednich, kontaktach. Niemniej jednak faktycznie urzeczywistnia się ona w obszarach interakcji między jej uczestnikami, wymiany usług, współdziałaniu, interioryzacji tożsamych celów, wzajemnego szacunku. Integracja zachodzi zatem na kilku płaszczyznach. Tradycyjnie wymienia się cztery: kulturalną, normatywną, komunikacyjną i funkcjonalną (za: Chodkowska, 2004: 15). Realizowane zadania w obszarze kształcenia integracyjnego pozostają w ścisłym związku ogólnych zadań edukacyjnych, są jednak w niektórych zakresach pogłębiane i rozszerzane. Nieco uogólniając, zadania te obejmują także procesy rehabilitacji. W związku ze zróżnicowanym poziomem możliwości uczniów częściej aniżeli w kształceniu ogólnodostępnym ma miejsce indywidualizowanie pracy uczniów, więcej aktywności wymaga kształtowania odpowiednich postaw zwłaszcza wobec uczniów niepełnosprawnych, inspirowanie interakcji oraz kształtowanie symetrycznych relacji między wszystkimi uczniami. Realizacja tych zadań sprzyja pojawianiu się swoistych antynomii. Ich przykłady znajdujemy w jednoczesnym indywidualizowaniu (koniecznym w realizacji celów dydaktycznych) oraz uspołecznianiu (łączonym z kształtowaniem umiejętności współpracy). Innym przykładem jest założona heterogeniczność grupy (typowa dla klasy integracyjnej), która w praktyce obniża jej zdolność integracyjną. Dokładna analiza założeń kształcenia integracyjnego oraz procesów edukacji w klasie/grupie integracyjnej pozwala dostrzec znacznie więcej takich sprzeczności (por. Gajdzica 2011: 153-155). Pomijając ich dokładną charakterystykę, warto zwrócić uwagę, że sprzyjają one kreowaniu wieloznacznych 
sytuacji wychowawczych niosących ze sobą konsekwencje w postaci negatywnych skutków dla spełniania roli ucznia przez dziecko niepełnosprawne, a często także służą autokreacji tożsamości człowieka upośledzonego.

Kształcenie integracyjne generuje zatem okoliczności balansowania między szansą a niebezpieczeństwem dla rozwoju uczniów z niepełnosprawnością. Szanse wynikają z ich bezpośredniego kontaktu z rówieśnikami o prawidłowym rozwoju, nabywania doświadczeń w środowisku ludzi pełnosprawnych, kształtowania umiejętności radzenia sobie z problemami będącymi namiastką tych spotykanych w społeczeństwie już po opuszczeniu murów szkoły. Niebezpieczeństwa wiążą się z możliwością ignorowania lub uwydatniania ich specjalnych potrzeb. Ich niedostrzeganie lub niedocenianie sprzyja generowaniu sytuacji trudnych, w których uczniowie ci nie radzą sobie z projektowanymi dla nich zadaniami. To zaś obniża ich samoocenę, utrudnia prawidłowe spełnianie roli ucznia (nierealizowanie programu nauczania, słabe oceny). W przypadku nadmiernego akcentowania specyficznych potrzeb mają miejsce okoliczności typowe dla wrastania w rolę ucznia upośledzonego. Jej atrybutem jest ciągłe oczekiwanie wsparcia (nawet $\mathrm{w}$ warunkach, kiedy jest ono zbyteczne), niesymetryczne relacje $\mathrm{z}$ rówieśnikami czy zepchnięcie na margines głównych działań podejmowanych na forum klasy. W efekcie takich okoliczności powstają warunki sprzyjające nabywaniu swoistej tożsamości Innego.

Do kwestii kluczowych w kreowaniu warunków sprzyjających rozwojowi należy definiowanie ucznia niepełnosprawnego i projektowanie na jego kanwie procesów socjalizacyjnych i edukacyjnych w przestrzeni klasy integracyjnej.

\section{Postrzeganie ucznia z niepełnosprawnością}

Rozpatrując sytuację szkolną ucznia niepełnosprawnego (zwłaszcza w przestrzeni klasy integracyjnej), warto zwrócić uwagę na kilka możliwych sposobów postrzegania jego właściwości, a nawet konstruowania jego roli. Przyjęcie jednego z prezentowanych niżej stanowisk warunkuje jego sytuację, ponieważ sama niepełnosprawność pozostaje $\mathrm{w}$ ścisłym związku $\mathrm{z}$ doświadczeniami ludzi niepełnosprawnych, ale także i osób pełnosprawnych wchodzących z nimi w interakcje. W tradycyjnym ujęciu doświadczenie to łączy się z negatywnymi odczuciami różnych opresji tych pierwszych (Barnes, Mercer, 2008) oraz uwydatnianiem odrębności przez tych drugich (Speck, 2005).

Pierwsze stanowisko wiąże się z biologicznym modelem niepełnosprawności, które zdeterminowane jest pojęciem normy fizjologicznej, a jego cechą konstytutywną jest uszkodzenie organizmu. W tym ujęciu niepełnosprawnym będzie uczeń z uszkodzeniami na przykład centralnego układu nerwowego, receptorów i anali- 
zatorów zmysłów, narządów ruchu itp. To podejście traktuje niepełnosprawność jako cechę stałą, często nieodwracalną. Było ono punktem wyjścia rozpatrywania edukacji szkolnej uczniów niepełnosprawnych przez wiele lat, a jego następstwem traktowanie niepełnosprawności jako kwestii indywidualnej dziecka. Główną ideą procesów kształcenia w tym ujęciu jest dynamizowanie rozwoju przez szeroko rozumiane procesy rehabilitacyjne, którym podporządkowana jest cała edukacja.

W ujęciu drugim na planie pierwszym są umieszczone specjalne potrzeby edukacyjne traktowane jako pochodna zaburzeń funkcjonalnych. Jest to stanowisko szczególnie widoczne w niektórych definicjach psychologicznych ujmujących niepełnosprawność jako jednostkowe zaburzenia funkcjonowania. Podstawą takiego postrzegania jest przeświadczenie, że zaburzenia w rozwoju zawsze generują odmienne od przeciętnych potrzeby edukacyjne, a ich niwelowanie łączy się z oddziaływaniem terapeutycznym oraz specjalnymi zabiegami dydaktyczno-wychowawczymi. To zaś niesie ze sobą konieczność (zwłaszcza w przypadku kształcenia integracyjnego i inkluzyjnego) nieustannego indywidualizowania. Także i w tym podejściu rehabilitacja (terapia) odgrywa kluczową rolę.

Kolejna propozycja postrzegania ucznia niepełnosprawnego zasadza się na specjalnej potrzebie realizacji potrzeb i celów, które w podstawowych wymiarach nie różnią się jednak zasadniczo od potrzeb uczniów pełnosprawnych (np. potrzeba uznania, sprawiedliwego traktowania, racjonalnych wymagań, czy cele możliwie wielostronnego rozwoju, optymalnego przygotowania do pełnienia społecznie, prawnie i kulturowo przypisanych ról). Do istotnych założeń w tym ujęciu należy przeświadczenie możliwych trudnościach w realizacji powszechnego programu każdego ucznia, także niepełnosprawnego, co oczywiście prowadzi do konieczności stosowania specjalnej pomocy. Jest ona jednak dodatkiem do powszechnego wychowania i kształcenia. Rehabilitacja (czy terapia) pełni zatem rolę służebną wobec edukacji.

Ostatnia $\mathrm{z}$ omawianych perspektyw postrzegania ucznia niepełnosprawnego została ulokowana w założeniach konstruktywizmu. Istotą tego podejścia jest założenie, że niepełnosprawność konstruowana jest przede wszystkim w toku zachodzących interakcji w klasie - między uczniami (pełno- i niepełnosprawnymi) i uczniami a nauczycielami. Niepełnosprawność ucznia jest zatem definiowana z punktu widzenia obserwatora i oparta na jego kryteriach, w których zostają zakreślone obszary normy wychowawczej i nurty powszechnych oddziaływań edukacyjnych (Gajdzica, 2010: 163).

W powszechnym, potocznym przekonaniu niepełnosprawność różni się od upośledzenia, które jest pojęciem pejoratywnym, naznaczającym. Jest to szczególnie widoczne w analizie społecznych konotacji upośledzenia umysłowego (Krause, 2010: 96-101). Sam termin upośledzenie oznacza utratę lub ograniczenie możliwości pełnego uczestnictwa człowieka w życiu społecznym (Dykcik, 2005: 18). Doty- 
czy zatem nie tylko samej osoby niepełnosprawnej, ale przede wszystkim jej relacji $\mathrm{z}$ otaczającą rzeczywistością. W takim podejściu samo źródło utraty, ograniczenia czy uniemożliwienia pełnego uczestnictwa człowieka w życiu społecznym jest kwestią drugorzędną. W związku z tym, analizując możliwe społeczne koncepcje niepełnosprawności, zauważamy, że niektóre z nich w sposób bezpośredni, a inne pośredni prowadzą do definiowania upośledzenia. Wydaje się jednak, że niepełnosprawność ucznia nie jest warunkiem wystarczającym, by społecznie był on postrzegany jako upośledzony.

\section{Nabywanie roli ucznia upośledzonego}

Uczeń określany mianem upośledzonego zatem $\mathrm{z}$ różnych przyczyn nie jest $\mathrm{w}$ stanie w pełni wypełniać powszechnej roli ucznia. Przypomnijmy, że polega ona na realizowaniu ogólnego programu nauczania (czyli zaliczania kolejnych partii materiału) oraz na zachowaniach zgodnych z obowiązującymi regułami w szkole (czyli postępowaniu w myśl uznanych za normalne wzorców, podejmowaniu działań ulokowanych w normach kulturowych, dokonywaniu wyborów adekwatnych do oczekiwań społecznych). Uogólniając - w potocznym znaczeniu - wskaźnikiem upośledzenia ucznia są następstwa niepełnosprawności, czyli:

- nierealizowanie powszechnego programu nauczania z powodu ograniczeń rozwojowych,

- realizowanie powszechnego programu nauczania, ale z dodatkowym wsparciem, które jest mu udzielane z powodu jego zaburzeń funkcjonalnych,

- niestosowanie się do powszechnie przyjętych reguł wyznaczających porządek i relacje w szkole z powodu zaburzeń funkcjonalnych.

Wskaźniki te są warunkiem koniecznym, ale niewystarczającym, muszą więc zostać uzupełnione o jeszcze jeden - uczeń ten, w związku ze swoimi ograniczeniami (także wyglądem), traktowany jest jako nieporadny, niewydolny, dysfunkcjonalny, naznaczony odmiennością.

Łatwo zauważyć, że uczeń, który nie realizuje powszechnego programu z powodu (w przeświadczeniu obserwatora) swojego lenistwa, nie należy do grupy upośledzonych. Analogicznie do tej grupy nie zalicza się uczniów wchodzących w konflikt z ogólnie przyjętymi normami społecznymi pod warunkiem, że jego nieobyczajne zachowanie (pozostające w sporze z powszechnym wzorem) nie jest wynikiem jego zaburzeń rozwojowych (poszczególnych funkcji). Zatem naznaczone upośledzenie jest następstwem wcześniejszej stwierdzonej niepełnosprawności oraz nadania mu tej właściwości przez obserwatora.

Co jednak się dzieje w przypadku ucznia z orzeczoną potrzebą kształcenia specjalnego (na podstawie niepełnosprawności), który realizuje powszechny program 
bez dodatkowego wsparcia, a jego zachowanie powszechnie wpisuje się w oczekiwania społeczne? Odpowiedź wydaje się oczywista - jest niepełnosprawny, ale nie jest upośledzony. Przynajmniej nie powinien nim być w aspekcie przytoczonych przykładów. Tymczasem rzeczywistość nie jest tak jednoznaczna. Także i w tym przypadku upośledzenie może zostać mu przypisane w wyniku stereotypu. Takie podejście uruchamia cały zbiór mechanizmów mimowolnego wrastania $\mathrm{w}$ rolę upośledzonego.

W praktyce inicjacja tej roli dokonuje się za pośrednictwem orzeczenia o potrzebie kształcenia specjalnego, które bywa wydawane nie tylko i wyłącznie w związku $\mathrm{z}$ faktem nierealizowania programu nauczania czy zachowywania się zgodnie z powszechnymi oczekiwaniami, ale na podstawie uszczerbku na zdrowiu - zaburzenia w rozwoju natury fizjologicznej. Inicjacja ta uruchamia proces przysposabiania do roli (por. Błeszyńska, 2001: 107), ponieważ niepełnosprawność zwykle jest łączona z niewydolnością społeczną, niemocą, dysfunkcjonalnością, a nawet dewiacją (Speck, 2005). Przyjmując, że role są zdefiniowane społecznie $\mathrm{w}$ postaci określonych zachowań, jakie powinna przyjmować jednostka (Giddens, 2004: 51) następuje proces wrastania w nią przez ucznia niepełnosprawnego, który de facto nie jest uczniem upośledzonym. Oczywiście nie może on zignorować oczekiwań społecznych formułowanych wobec niego bez własnego uszczerbku.

$\mathrm{Na}$ etapie przysposabiania do roli ucznia upośledzonego pojawiają się dwie równoległe płaszczyzny. Pierwsza obejmuje proste skutki naznaczenia (działania często podejmowane w trosce o samego ucznia). Są one szczególnie widoczne w nadmiernym uwydatnianiu specjalnych różnic w potrzebach lub przynajmniej akcentowaniu odmiennej drogi ich realizacji (to już zależy od koncepcji postrzegania niepełnosprawności). W efekcie tego podejścia pojawia się swoisty neofityzm indywidualizacji, która w ocenie zatroskanego nauczyciela jest już nie tyle środkiem (narzędziem koniecznym), ale celem samym w sobie. W konstruowaniu programu staje się ona punktem wyjścia do projektowania poszczególnych działań, nawet w okolicznościach całkiem zbytecznych (kiedy uczeń niepełnosprawny jest $\mathrm{w}$ stanie poradzić sobie $\mathrm{z}$ realizacją celu za pomocą powszechnych narzędzi). Uporczywa indywidualizacja prowadzi do zaburzeń socjalizacji. Uczeń traktowany zawsze i wszędzie wyjątkowo nie nabywa kompetencji współpracy, współdziałania, kompromisu, zostaje pozbawiony doświadczania zwykłych porażek i sukcesów. Na tej podstawie konstytuuje się jego obraz jako Innego. To zaś prowadzi do zaburzonych, niesymetrycznych relacji z jego rówieśnikami, rozpatrywania jego miejsca w perspektywie on - my (mniejszość versus większość). Warto podkreślić, że w społecznym ujęciu są to typowe wskaźniki definiowania niepełnosprawności na podstawie roli w grupie (np. Speck, 2005: 229-230). 
Druga płaszczyzna dotyczy tożsamości ucznia. Jest to wyjątkowo dobrze widoczne w jej interakcyjnym modelu. Centralnym ogniwem są tu procesy interpretowania (przez samego ucznia) i definiowania tego, co dzieje się w jego otoczeniu. To zaś prowadzi do przyjęcia określonego punktu widzenia, czyli sposobu postrzegania siebie w otaczającej rzeczywistości (Nikitorowicz, 2009: 343). Tożsamość osobista wprawdzie jest konstruowana na kanwie interakcji z otaczającą rzeczywistością, ale centralne znaczenie w jej kształtowaniu mają wybory własne dokonywane na podstawie ocen rzeczywistości i podejmowane działania (Giddens, 2004: 52). Te zaś są efektem dopasowania się do narzuconej roli. Przypomnijmy, że indywidualna istota roli jest określana nie przez jednostkę, lecz przez społeczeństwo, a oczekiwania zachowań związane z rolami są wiążące dla jednostki. Oznacza to, że nie może ona ich zignorować bez uszczerbku dla siebie (Dahrendorf, 2005: 312). Trudno zatem zaprzeczyć, że tożsamość osobista ucznia upośledzonego jest skutkiem nie tyle samej niepełnosprawności, co raczej określonych założeń programowych oraz konkretnych działań nauczyciela ukierunkowanych na podniesienie jakości jego procesu kształcenia.

Teza ta ukazuje bodajże największą sprzeczność wewnętrzną założeń edukacji integracyjnej. Trudno bowiem przypuszczać, że każdy uczeń niepełnosprawny (z zaburzeniami funkcjonalnymi) jest $\mathrm{w}$ stanie realizować powszechny program kształcenia bez specjalnego wsparcia, zapewne część uczniów niepełnosprawnych wcale nie jest w stanie go zrealizować. Zatem nauczyciel stojący na straży realizacji treści kształcenia (przede wszystkim z tego zadania jest rozliczany) nieświadomie jest jednocześnie głównym animatorem konstruowania jednostkowej tożsamości ucznia upośledzonego umysłowo. Niewątpliwie tożsamość tę (również zwykle nieświadomie) wzmacniają także uczniowie.

Podejście to pozostaje w ścisłym związku z podmiotową perspektywą upośledzenia ujawnioną w triadzie przez Małgorzatę Kościelską (Kościelska, 1995). Wprawdzie jej koncepcja dotyczy przede wszystkim osób z upośledzeniem umysłowym, ale opisany mechanizm: upośledzonego Ja, upośledzonego umysłu oraz upośledzonego życia wyjaśnia także sytuację szkolną ucznia niepełnosprawnego. Wszelkie próby obrony swojej niezależnej tożsamości są bowiem udaremniane przez otaczające środowisko, ponieważ są identyfikowane jako wykraczające poza zaprojektowaną rolę ucznia upośledzonego. W tych okolicznościach pozostaje więc już tylko pełnienie tej roli, co z kolei sprzyja nabywaniu wyuczonej bezradności, manipulowaniu swoimi ograniczeniami w celu osiągania komfortowych (zwykle rozleniwiających) warunków uczenia się. Objawiają się one ciągłym oczekiwaniem wsparcia, nieuzasadnionym obniżaniem progu wymagań, zwalnianiem z obowiązków przynależnych wszystkim uczniom. 


\section{Konkluzje końcowe}

Poszukiwanie rozwiązań przydatnych $\mathrm{w}$ praktyce edukacyjnej nie jest łatwe. Pierwszym z nich jest znajomość potencjału rozwojowego ucznia. To na podstawie trafnej, funkcjonalnej diagnozy nauczyciel może konsekwentnie projektować zadania, które pozostają w zasięgu możliwości ucznia. Niewątpliwie zatem kompetencje diagnostyczne nauczyciela szkoły integracyjnej (a w przypadku kształcenia inkluzyjnego także ogólnodostępnej) są punktem wyjścia w podejmowaniu trafnych działań. Z kolei konsekwencją ogólnej wiedzy o mechanizmach funkcjonowania osób niepełnosprawnych (kompetencje merytoryczne) jest projektowanie zadań integrujących, w trakcie których zostają budowane symetryczne relacje między wszystkimi uczniami. W tym kontekście na plan pierwszy wysuwają się mocne strony uczniów niepełnosprawnych. Wszak niepełnosprawność (ta, którą napotykamy w szkołach ogólnodostępnych i integracyjnych, nie jest głęboka) nie jest stanem zawłaszczającym wszystkie sfery życia (działalności szkolnej). Zwykle uczeń z określonym zaburzeniem funkcji ma wiele mocnych stron. Warto zatem zadbać, by miał szanse je rozwinąć i uwydatnić na forum zespołu klasowego. To zaś sprzyja niwelowaniu stygmatu niewydolności i dysfunkcjonalności. Innym ważnym problemem jest traktowanie indywidualizacji jako ostatecznej formy organizacji zajęć, a nie jako środka - celu będącego panaceum na wszelkie problemy. To zaś wymaga zmiany sposobu myślenia (kompetencje metodyczne) z: indywidualizowania wtedy, kiedy to możliwe, na: indywidualizowanie, kiedy to konieczne.

\section{Literatura}

Barnes C., Mercer G. (2008). Niepełnosprawność. Tłum. P. Morawski. Warszawa Błeszyńska K. (2001). Niepetnosprawność a struktura identyfikacji społecznych. Warszawa

Chodkowska M. (2004). Socjopedagogiczne problemy edukacji integracyjnej dzieci z obciązeniami biologicznymi i środowiskowymi. Warszawa

Dahrendorf R. (2005). Homo Sociologicus. O historii, znaczeniu i granicach kategorii roli społecznej. (W:) Socjologia. Lektury. P. Sztompka, M. Kucia (red.). Przekład P. Polak. Kraków

Dykcik W. (2005). Wprowadzenie w przedmiot pedagogiki specjalnej. (W:) Pedagogika specjalna. W. Dykcik (red.). Poznań

Gajdzica Z. (2010). Codzienność ucznia niepetnosprawnego - perspektywa badacza. (W:) Codzienność w szkole. Szkoła w codzienności, Wychowanie. Pojęcia, procesy, konteksty - interdyscyplinarne ujęcie. T. 5. M. Dudzikowa, M Czerepaniak-Walczak (red.). Gdańsk

Gajdzica Z. (2011). Sytuacje trudne w opinii nauczycieli klas integracyjnych. Kraków

Giddens A. (2004). Socjologia. Warszawa

Kościelska M. (1995). Oblicza upośledzenia. Warszawa

Krause A. (2010). Wspótczesne paradygmaty pedagogiki specjalnej. Kraków 
Nikitorowicz J. (2009). Edukacja regionalna i międzykulturowa. Warszawa

Speck O. (2005). Niepetnosprawni w społeczeństwie. Podstawy ortopedagogiki. Tłum. W. Zeidler, A. Skrzypek, D. Gącza, D. Szaranowicz.Gdańsk

\section{Why Does a Child With Impairment Usually Become a Disabled Learner?}

\section{Summary}

Being a child with impairment does not necessarily mean being a disabled learner. However, it cannot be denied that the limitation of ability hinders fulfilling the child's typical roles, including one of the most significant - the role of a learner. Moreover, there are numerous mechanisms which enhance disabled children's rooting into the role of the disabled and their acquiring the identity adequate to this role. The presented study aims at the identification of these mechanisms in the area of integrated education as well as at showing possible consequences for educational practice and the development of disabled learners.

What becomes a starting point in the presented discussion is the issue of viewing and defining the disabled learner. With certain simplification, there are several standpoints in this area.

The first is related to the biological model of disability, which is determined by the notion of physiological norm and for which organism impairment is a constitutive feature. In this approach, the disabled learner is the learner with damage, e.g. of the central nervous system, of sensory receptors and analyzers, of motor organs etc. This standpoint views disability as a permanent, often irreversible, feature. For many years, it has constituted the starting point for considering school education of disabled learners and has resulted in treating disability as an individual issue of a child. The major idea of educational processes in this perspective is dynamizing the development by broadly understood rehabilitation processes, to which the whole education is subordinated.

What ranks as priority in the second standpoint are special educational needs treated as a derivative of functional disorders. This point of view is particularly visible in some psychological definitions presenting disability as individual functional disorders. This is based on the belief that developmental disorders always generate non-average educational needs and that their leveling is associated with therapeutic influence and special didactic and educational undertakings. This results in the necessity of unceasing individualization, especially in the case of integrated and inclusive education. Also in this approach, rehabilitation (therapy) is of key significance.

Another way of viewing the disabled learner is based on the special necessity of fulfilling needs and aims which fundamentally do not differ significantly from the needs of fully able learners (e.g. the need for recognition, just treatment, rational demands; the aim of possibly multisided development or of optimal preparation for fulfilling socially, legally and culturally attributed roles). What this approach essentially assumes are possible difficulties in fulfilling the mainstream curriculum for each learner, also the disabled, which necessitates the application of special aid. Nevertheless, such help is only an addition to mainstream education. Thus, rehabilitation (or therapy) fulfills a subordinate role to education. 
The last perspective of viewing the disabled learner which is discussed here is situated in the assumptions of constructivism. It is essential in this approach to assume that disability is constructed mostly in the course of classroom interactions - among (fully able and disabled) learners and between learners and teachers. Therefore, the learner's disability is defined here from the point of view of the observer and is based on their criteria, in which the areas of educational norm are specified as well as the currents of common educational influence.

Each of the presented standpoints allows for slightly different handling of the disabled learner's school problems. In the presented article, the discussed issues are rooted in the last constructivist approach.

Choosing the integrated form of education for studying the acquisition of the learner's impaired identity is not accidental. The widely popular in Poland model of integrated education involves many inner contradictions. Space of the integrated class/group is a place where numerous disjunctive assumptions clash. Integration itself is the process of balancing between a chance and a threat for disabled learners. These theses are illustrated in the first part of the study. The second comprises the issues of the disabled learner. What is considered in the third part are the mechanisms of rooting into the role of the disabled learners and of acquiring the identity typical for this role. The whole is complemented by final conclusions. 